\title{
Tracking the evolution of sex chromosome systems in Melanoplinae grasshoppers through chromosomal mapping of repetitive DNA sequences
}

\author{
Octavio M Palacios-Gimenez ${ }^{1}$, Elio R Castillo², Dardo A Martí ${ }^{2}$ and Diogo C Cabral-de-Mello ${ }^{*^{*}}$
}

\begin{abstract}
Background: The accumulation of repetitive DNA during sex chromosome differentiation is a common feature of many eukaryotes and becomes more evident after recombination has been restricted or abolished. The accumulated repetitive sequences include multigene families, microsatellites, satellite DNAs and mobile elements, all of which are important for the structural remodeling of heterochromatin. In grasshoppers, derived sex chromosome systems, such as neo- $X Y{ }^{\lambda} / X X+$ and neo- $X_{1} X_{2} Y \hat{\delta} / X_{1} X_{1} X_{2} X_{2}+$, are frequently observed in the Melanoplinae subfamily. However, no studies concerning the evolution of sex chromosomes in Melanoplinae have addressed the role of the repetitive DNA sequences. To further investigate the evolution of sex chromosomes in grasshoppers, we used classical cytogenetic and FISH analyses to examine the repetitive DNA sequences in six phylogenetically related Melanoplinae species with $X 0 \hat{\partial} / X X+$, neo- $X Y \hat{\delta} / X X+$ and neo- $X_{1} X_{2} Y \hat{\delta} / X_{1} X_{1} X_{2} X_{2} q$ sex chromosome systems.

Results: Our data indicate a non-spreading of heterochromatic blocks and pool of repetitive DNAs (Cot-1 DNA) in the sex chromosomes; however, the spreading of multigene families among the neo-sex chromosomes of Eurotettix and Dichromatos was remarkable, particularly for 5 S rDNA. In autosomes, FISH mapping of multigene families revealed distinct patterns of chromosomal organization at the intra- and intergenomic levels.

Conclusions: These results suggest a common origin and subsequent differential accumulation of repetitive DNAs in the sex chromosomes of Dichromatos and an independent origin of the sex chromosomes of the neo-XY and neo- $X_{1} X_{2} Y$ systems. Our data indicate a possible role for repetitive DNAs in the diversification of sex chromosome systems in grasshoppers.
\end{abstract}

\section{Background}

For more than a century, the evolution of the sex chromosomes and the genetics of sex determination have been the source of some of the most intriguing questions in evolutionary biology and have been the focus of many genetic and cytological studies (see for example [1-12]). Sex chromosomes evolve from a pair of homologous autosomes [13], and the restriction or absence of recombination and the further accumulation of repetitive sequences

\footnotetext{
* Correspondence: mellodc@rc.unesp.br

'UNESP - Univ Estadual Paulista, Instituto de Biociências/IB, Depto. de Biologia, Rio Claro/SP, Brazil

Full list of author information is available at the end of the article
}

on chromosomes $\mathrm{Y}$ or $\mathrm{W}$ are important events in the differentiation of these elements [14-16].

Based on evidence obtained from molecular studies in different taxa, DNA sequence restructuring occurs within new sex chromosome regions ( $\mathrm{Y}$ or $\mathrm{W})$ during the early evolution of the sex chromosomes, and this process involves modifications to the chromatin structure and the insertion of repetitive DNA sequences. These morphological and genetic changes are consistent with the abolition of recombination, which precedes the genetic degeneration of neo-Y or neo-W chromosomes with unknown fates [1,15-21].

Among the inserted repetitive DNA sequences, a remarkable preponderance of mobile elements, satellite

\section{Biomed Central}


DNAs, microsatellites and multigene families, which can remodel euchromatic structures into heterochromatin, has been observed [17,22-25]. Non-recombining regions of the $\mathrm{Y}$ chromosome containing accumulated repetitive DNAs have been well documented in, for example, mammalian species $[11,26]$ and Drosophila melanogaster [27], in which the sex chromosome systems are evolutionarily ancient $[8,28]$. The accumulation of repetitive sequences, even in young sex chromosomes, has also been observed in other organisms, such as Drosophila miranda [19], Silene latifolia [29-31] and Rumex acetosa [23].

Grasshopper species are characterized by a high frequency of $2 \mathrm{n}=23 \hat{\gamma} / 24 q$ karyotypes comprising acrotelocentric chromosomes and $\mathrm{X} 0 \hat{\mathrm{\lambda}} / \mathrm{XX}$ 을 sex chromosome determination system. According to White [32] and Hewitt [4], this karyotype is considered atavistic, at least for Caelifera. Although grasshoppers within Acrididae have this form of karyotypic stability and $\mathrm{X} 0 \hat{\curvearrowright} / \mathrm{XX}+$ sex chromosome system, the Melanoplinae subfamily shows an unusually high frequency of derived neo-sex chromosome systems, which have been observed in at least 50 species [33-35]. This sex chromosome variability primarily reflects the occurrence of Robertsonian fusions (Rb-fusions), which generate complex neo- $\mathrm{XY} \hat{\sigma} / \mathrm{XX}$ + and neo- $\mathrm{X}_{1} \mathrm{X}_{2} \mathrm{Y} \precsim /$ $\mathrm{X}_{1} \mathrm{X}_{1} \mathrm{X}_{2} \mathrm{X}_{2}$ q sex chromosome systems [32,35-37].

In contrast with other insect orders such as Lepidoptera [38-41] and Diptera [6,7,21] in which the evolution of the sex chromosomes has been studied by mapping distinct classes of DNAs, there is a complete lack of knowledge at the molecular level concerning the evolution of the neo-sex chromosomes in grasshoppers and the mechanisms that underlie the degeneration of the neo-Y chromosome. The great diversity of the sex chromosome systems observed in Melanoplinae suggests that this group represents an excellent experimental model to analyze any changes in patterns of linked gene groups within the sex chromosomes. With the aim of a better understanding of the evolution of sex chromosomes in grasshoppers we used classical cytogenetic techniques and fluorescence in situ hybridization (FISH) to analyze five multigene families, telomeric repeats and repetitive DNA fractions $\left(C_{0} t-1\right.$ DNA fraction) in six phylogenetically related Melanoplinae species: Chlorus vittatus and Ch. chiquitensis; Eurotettix minor and E. brevicerci; and Dichromatos lilloanus and D. schrottkyi $[42,43]$. These species present different sex chromosomes, including $\mathrm{X} 0$, neo-XY and neo- $\mathrm{X}_{1} \mathrm{X}_{2} \mathrm{Y}$ in males ([33,34], this work). We focused mainly on the dynamics of repetitive DNA incorporation into new sex chromosomes as an evolutionary force that contributes to the chromosomal diversification of this group, and we examined the evidence for independent or common origins of the neosex chromosome systems in the analyzed species.

\section{Results}

\section{Meiosis and karyotypes}

Different diploid numbers were observed in the six species studied: $2 \mathrm{n}=23 \hat{\delta} / 249$ in Chlorus vittatus and Eurotettix brevicerci, $2 \mathrm{n}=19 \hat{\jmath} / 20$ + in Ch. chiquitensis, $2 \mathrm{n}=22 \hat{\jmath} / 22 q$ in E. minor and $2 \mathrm{n}=21 \hat{\jmath} / 22+$ in Dichromatos lilloanus and D. schrottkyi (Figure 1; Table 1). The autosomes were, in general, acro-telocentric; however, in Ch. chiquitensis, pair 5 was submetacentric. Three types of sex chromosome systems were observed: $\mathrm{X}_{0}{ }^{-} / \mathrm{XX}+$ in $\mathrm{Ch}$. vittatus, Ch. chiquitensis and E. brevicerci; neo-XY $\lesssim / \mathrm{XX}$ + in E. minor and neo- $\mathrm{X}_{1} \mathrm{X}_{2} \mathrm{Y} \delta / \mathrm{X}_{1} \mathrm{X}_{1} \mathrm{X}_{2} \mathrm{X}_{2} \odot$ in D. lilloanus and $D$. schrottkyi (Figure 1; Table 1).

The $\mathrm{X}$ sex chromosome in the $\mathrm{X} 0 \hat{\curvearrowright} / \mathrm{XX}+$ system was acro-telocentric, showing negative heteropycnotic behavior during metaphase I and variability in size among the species (Figure 1). In E. minor, the neo-XY $\lesssim / \mathrm{XX} \bigcirc$ sex pair was formed by a metacentric neo-X, the product of $\mathrm{Rb}$-fusion between the ancestral $\mathrm{X}$ and an autosome, whose homologue has become a telocentric neo-Y. The neo-sex chromosomes showed distal contact during metaphase I, and adopted the typical L-shaped configuration (Figure 1). Finally, in the Dichromatos species, neo-sex chromosomes were formed from the metacentric neo- $\mathrm{X}_{1}$, the acro-telocentric neo- $\mathrm{X}_{2}$ and the metacentric neo-Y, being the neo-Y chromosome the largest element. At metaphase I, the neo-sex chromosomes were observed in the typical convergent orientation of a Robertsonian trivalent, with the XR arm distally associated with the YL arm of the neo-Y chromosome and the YR arm of the neo-Y chromosome distally associated with the neo- $\mathrm{X}_{2}$ chromosome (Figure 1).

\section{Heterochromatin, $\mathrm{C}_{0} \mathrm{t}-1 \mathrm{DNA}$ and telomeric mapping}

In all of the species analyzed here, C-positive blocks were observed in the pericentromeric region of all complements, including the sex chromosomes (Figure 2). These C-positive regions were labeled by the $C_{0} t-1$ DNA fractions obtained from each species, except the pericentromeric region of the neo-Y chromosome in $D$. lilloanus. Additionally, terminal blocks were detected in the Ch. chiquitensis, Eurotettix and D. lilloanus chromosomes. In E. brevicerci, interstitial blocks were also observed in pairs 1, 3 and 9 (Figure 2). In the Dichromatos species, the specimens used to perform the FISH analysis with the $C_{0} t-1$ DNA probes carried B chromosomes that presented pericentromeric, interstitial or terminal blocks (Figure 2).

The $\mathrm{CMA}_{3}$ /DAPI fluorochrome staining revealed homogeneous DAPI staining (results not shown) and distinct patterns of $\mathrm{G}+\mathrm{C}$-rich blocks $\left(\mathrm{CMA}_{3}\right.$ positive) as follows: Ch. vittatus, all pericentromeric regions; Ch. chiquitensis, pericentromeric regions of pairs 3, 5 and the $\mathrm{X}$ chromosome; E. brevicerci, interstitial region 


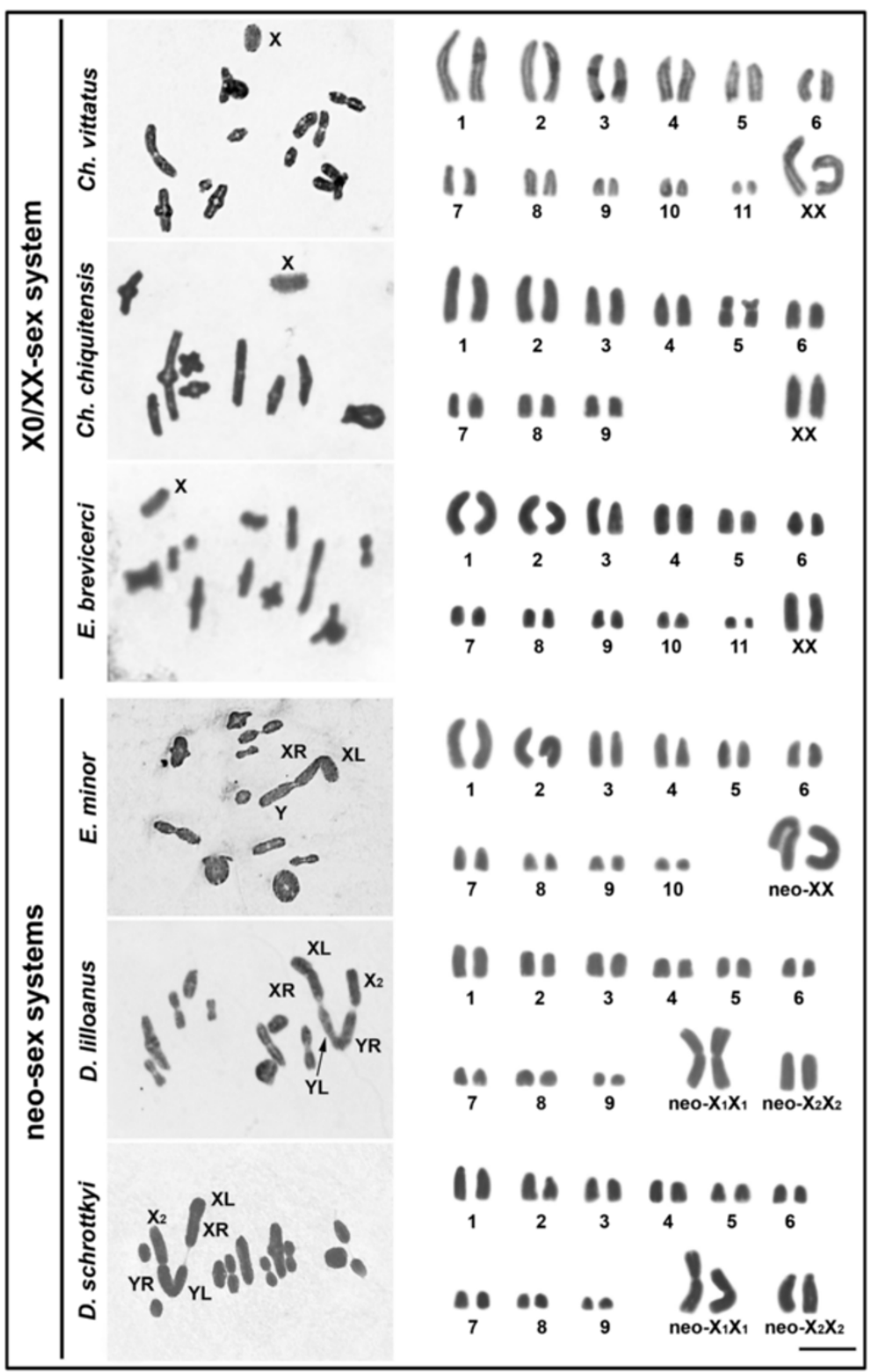

Figure 1 Conventional staining of male metaphase I (left panel) and female mitotic karyotypes (right panel). The sex-chromosome system types and the species names are shown directly in the figure. The sex chromosomes and chromosome arms of the neo-sex chromosomes involved in Rb-fusions are indicated. $\mathrm{XL}$ : arm derived from the original $\mathrm{X}$ chromosome fused to an autosome; XR: autosomal arm of the neo-X that shares homology with the neo-Y; YL: arm that shares homology with the XR arm; YR: arm that shares homology with the neo$\mathrm{X}_{2}$ chromosome. Bar $=5 \mu \mathrm{m}$.

of pair 6 and pericentromeric regions of the $\mathrm{X}$ chromosome and pair 9 (heteromorphic); E. minor, pericentromeric region of pair 5 and the neo-X chromosome and the distal region of pair $7 ; D$. lilloanus, pericentromeric regions of pair 5 and the neo- $\mathrm{X}_{1}$ chromosome; $D$. schrottkyi, pericentromeric regions of pair 4 and the neo- $\mathrm{X}_{1}$ and neo- $\mathrm{X}_{2}$ chromosomes (Figure 3 ).

In all species with $\mathrm{X} 0 \hat{\gamma} / \mathrm{XX}+$ sex system and those with Rb-fusion-derived sex chromosomes (neo-XY $\hat{\delta}$ / $\mathrm{XX}$, neo- $\mathrm{X}_{1} \mathrm{X}_{2} \mathrm{Y} \curvearrowright / \mathrm{X}_{1} \mathrm{X}_{1} \mathrm{X}_{2} \mathrm{X}_{2}+$ ), only terminal sites were observed with a telomeric probe in both the autosomes (result not shown) and the sex chromosomes (Figure 3, insets).

\section{Cytogenetic mapping of multigene families}

FISH analysis with an $18 \mathrm{~S}$ rDNA probe revealed signals in two autosomal pairs in Ch. vittatus, the $\mathrm{X}$ chromosome of Ch. chiquitensis and one pair of autosomes in $E$. brevicerci and E. minor; an additional cluster in the $\mathrm{X}$ chromosome of E. brevicerci was also observed (Table 1; 
Table 1 Species, locality, number of males and females (M/F), diploid numbers and chromosomal positions of multigene families in grasshoppers from the Chlorus, Eurotettix and Dichromatos genera studied in this paper

\begin{tabular}{|c|c|c|c|c|c|c|c|c|}
\hline Species & Locality & $\begin{array}{l}\text { Number of } \\
\text { individuals (M/F) }\end{array}$ & $2 n$ & $\begin{array}{l}18 \mathrm{~S} \\
\mathrm{rDNA}\end{array}$ & $\begin{array}{l}\text { H3 histone } \\
\text { gene }\end{array}$ & 5S rDNA & $\begin{array}{l}\text { U1 } \\
\text { snDNA }\end{array}$ & $\begin{array}{l}\text { U2 } \\
\text { snDNA }\end{array}$ \\
\hline \multirow{2}{*}{$\begin{array}{l}\text { Ch. } \\
\text { vittatus }\end{array}$} & \multirow[t]{2}{*}{ Parque Nacional Ybycuí (Paraguay) } & \multirow[t]{2}{*}{$15 / 2$} & $323 / \times 0$ & \multirow[t]{2}{*}{$3 p c ; 6 d$} & \multirow[t]{2}{*}{$7 \mathrm{i}$} & \multirow[t]{2}{*}{$3 \mathrm{i} ; 4 \mathrm{~d} ; 6 \mathrm{i}$} & \multirow[t]{2}{*}{$4 d$} & \multirow[t]{2}{*}{1 i; 2 i; 9} \\
\hline & & & 우24/XX & & & & & \\
\hline \multirow{2}{*}{$\begin{array}{l}\text { Ch. } \\
\text { chquitensis }\end{array}$} & \multirow{2}{*}{ Corumba (Brazil) } & \multirow[t]{2}{*}{$9 / 2$} & ふ19/X0 & \multirow[t]{2}{*}{$X p c$} & \multirow[t]{2}{*}{$7 \mathrm{pc}$} & \multirow[t]{2}{*}{$6 i$} & \multirow[t]{2}{*}{$4 d$} & \multirow[t]{2}{*}{$1 \mathrm{i} ; 2 \mathrm{i}$} \\
\hline & & & q $20 / X X$ & & & & & \\
\hline \multirow{2}{*}{$\begin{array}{l}\text { E. } \\
\text { brevicerci }\end{array}$} & \multirow[t]{2}{*}{ Botucatu (Brazil) } & \multirow[t]{2}{*}{$15 / 9$} & $\lesssim 23 / \times 0$ & \multirow{2}{*}{$\begin{array}{l}X p c ; 3 \\
p c\end{array}$} & \multirow[t]{2}{*}{$7 \mathrm{pr}$} & \multirow[t]{2}{*}{$3 i$} & \multirow[t]{2}{*}{$4 d$} & \multirow[t]{2}{*}{$1 \mathrm{i} ; 9 \mathrm{pc}$} \\
\hline & & & q24/XX & & & & & \\
\hline \multirow[t]{6}{*}{ E. minor } & \multirow[t]{2}{*}{ Paraguarí (Paraguay) } & \multirow[t]{2}{*}{$16 / 4$} & $\delta 22 / X Y$ & \multirow[t]{2}{*}{$3 \mathrm{pc}$} & \multirow[t]{2}{*}{$5 d$} & \multirow{2}{*}{$\begin{array}{l}3 \text { pc; } 5 \text { pr; } \\
\text { XR i }\end{array}$} & \multirow{2}{*}{$\begin{array}{l}4 \mathrm{~d} ; \mathrm{XR} \mathrm{i} \\
\text { Y i }\end{array}$} & \multirow{2}{*}{$1 \mathrm{i} ; 2 \mathrm{i}$} \\
\hline & & & 우22/XX & & & & & \\
\hline & Atyra (Paraguay) & $2 / 0$ & & & & & & \\
\hline & Altos (Paraguay) & $1 / 0$ & & & & & & \\
\hline & Parque Nacional Ybycuí (Paraguay) & $10 / 1$ & & & & & & \\
\hline & Ybycuí (Paraguay) & $7 / 0$ & & & & & & \\
\hline \multirow[t]{2}{*}{$\begin{array}{l}\text { D. } \\
\text { lilloanus }\end{array}$} & \multirow[t]{2}{*}{$\begin{array}{l}\text { Reserva Provincial Yaguaroundí (Argentina) } \\
\text { Eldorado (Argentina) }\end{array}$} & $30 / 35$ & $\begin{array}{l}O^{2} 21 / \\
X_{1} X_{2} Y\end{array}$ & \multirow[t]{2}{*}{$\begin{array}{l}\mathrm{X}_{1} \mathrm{pc} ; 5 \\
\mathrm{pr}\end{array}$} & \multirow[t]{2}{*}{$\begin{array}{l}1-9 p c_{;} X_{1} \\
p c ; x_{2} p c\end{array}$} & $\begin{array}{l}3 \text { i; YL pr, i, } \\
\text { d; YR pr }\end{array}$ & $2 \mathrm{i}$ & $\begin{array}{l}1 \mathrm{i} ; 6 \mathrm{pr} ; \\
\mathrm{YL} \mathrm{pr}\end{array}$ \\
\hline & & $0 / 2$ & $\begin{array}{l}+22 / \\
x_{1} x_{1} x_{2} x_{2}\end{array}$ & & & & & \\
\hline $\begin{array}{l}\text { D. } \\
\text { schrottkyi }\end{array}$ & Eldorado (Argentina) & $2 / 4$ & $\begin{array}{l}321 / \\
X_{1} X_{2} Y\end{array}$ & $\begin{array}{l}\mathrm{X}_{1} \mathrm{pc} ; 4 \\
\mathrm{pr}\end{array}$ & $5 \mathrm{pr}$ & $\begin{array}{l}2 \mathrm{i} ; \mathrm{YL} \mathrm{i} ; \mathrm{YR} \\
\mathrm{pr}, \mathrm{i}\end{array}$ & $3 d$ & $1 \mathrm{i} ; 5 \mathrm{pr} *$ \\
\hline & & & $\begin{array}{l}\text { O22/ } \\
x_{1} x_{1} x_{2} x_{2}\end{array}$ & & & & & \\
\hline
\end{tabular}

$p c=$ pericentromeric; $p r=$ proximal; $i=$ intersticial; $d=$ distal. * indicate the occurrence of heteromorphism.

Figure 4). In the Dichromatos species, signals were detected in the neo- $\mathrm{X}_{1}$ chromosome and in one autosomal pair (D. lilloanus pair 5 and D. schrottkyi pair 4) (Table 1; Figure 4).

Hybridization signals of the $5 \mathrm{~S}$ rDNA probe were observed in three autosomal pairs of Ch. vittatus, but only in one pair of autosomes in Ch. chiquitensis and E. brevicerci (Table 1; Figure 4). Eurotettix minor showed clusters of the 5S rDNA genes in two autosomal pairs and in the XR arm of the neo-X chromosome, whereas D. lillonaus and D. schrottkyi each showed one cluster in a pair of autosomes and multiple 5S rDNA sites in the neo-Y chromosome (Table 1; Figure 4).

In four species, Ch. vittatus, Ch. chiquitensis, E. brevicerci and $E$. minor, the U1 snRNA gene was distally located in pair 4. Additionally, U1 snRNA was present at interstitial sites in the XR and neo-Y chromosomes of $E$. minor. Dichromatos lilloanus and D. schrottkyi showed U1 snDNA clusters only in one bivalent (Table 1; Figure 5). U2 snDNA clusters were located interstitially in two autosomal pairs in the Chlorus species, and in Ch. vittatus, U2 snDNA was detected in an additional autosomal pair. In the Eurotettix species, these sequences were observed in two autosomal pairs. Dichromatos showed hybridization signals in two autosomal pairs; however, this gene cluster was also located on the YL arm in D. lilloanus (Table 1; Figure 5).
Finally, FISH analysis of histone H3 revealed conserved hybridization signals in pair 7 of $C h$. vittatus, Ch. chiquitensis and E. brevicerci. Eurotettix minor and D. schrottkyi presented the histone $\mathrm{H} 3$ cluster in the distal and interstitial regions of pair 5, respectively; whereas in D. lilloanus, this gene was spread throughout the pericentromeric regions of all chromosomes, except for the neo-Y chromosome (Table 1; Figure 6).

The FISH results showing the chromosomal locations of the multigene families are summarized in Table 1, and the FISH results for the sex chromosomes are summarized in Figure 7, except for those obtained using the telomeric probe.

\section{Discussion}

General organization of repetitive DNAs in autosomes

The general distribution patterns of the C-positive blocks found in the studied species were similar to those reported for other grasshopper species and occurred as pericentromeric blocks in the autosomal complements $[34,44,45]$. However, other repetitive DNA rich regions were detected using the $C_{0} t-1$ DNA fraction, including telomeres and interstitial areas.

For the multigene families, intra- and intergenomic variability were observed for the distinct sequences and species. Our findings revealed remarkable variability in the number and location of major rDNA genes; this is 


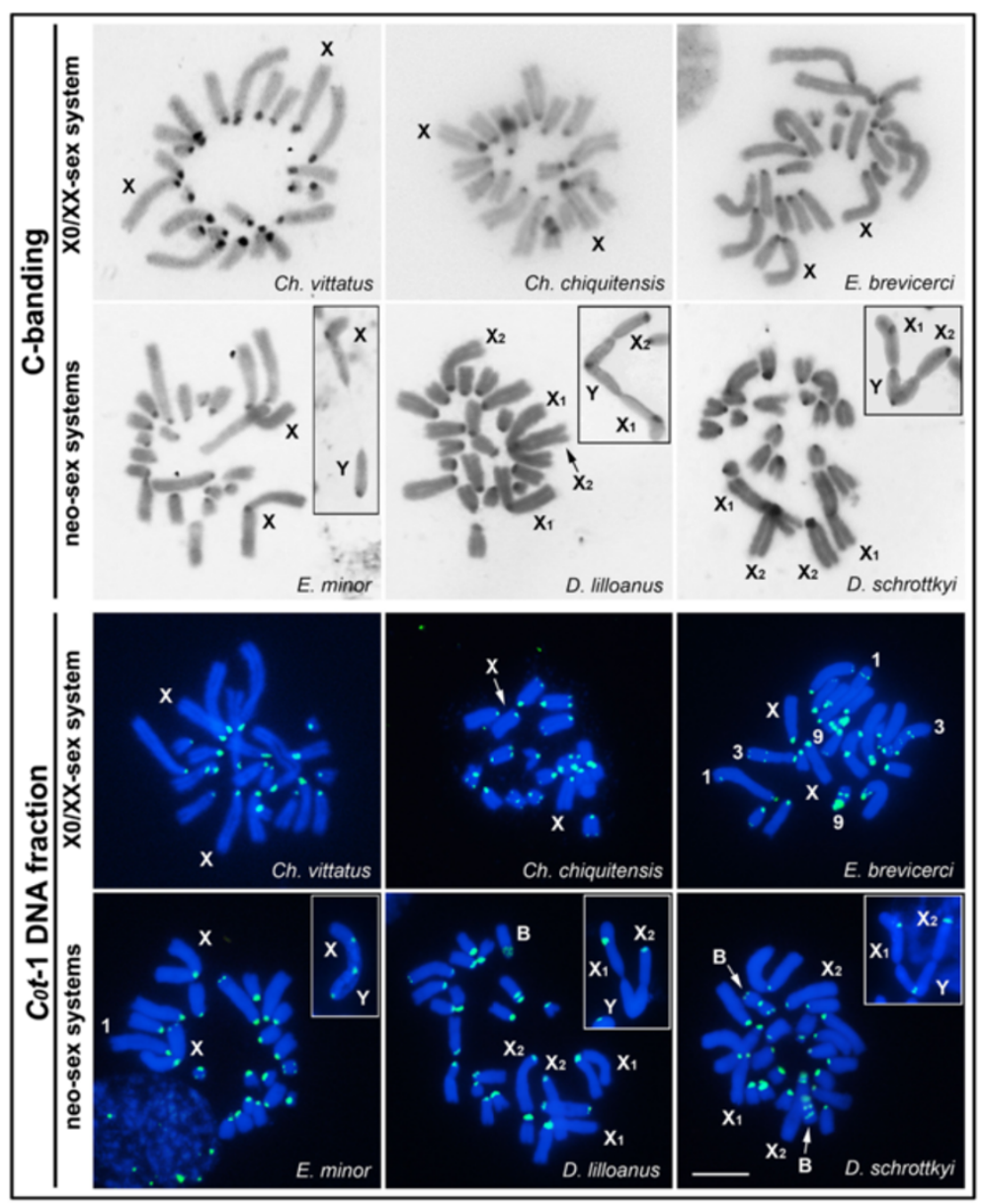

Figure $2 \mathrm{C}$-banding and $C_{0} t-1$ DNA fractions in female mitotic chromosomes. The species names and the types of sex chromosome determination systems are indicated in each figure. Inserts show the locations of C-banding and $C_{0} t-1$ DNA fractions in the neo-sex chromosomes during meiosis. Note the absence of the $C_{0} t-1$ DNA fraction in the neo-Y chromosome of D. lilloanus. Bar $=5 \mu \mathrm{m}$.

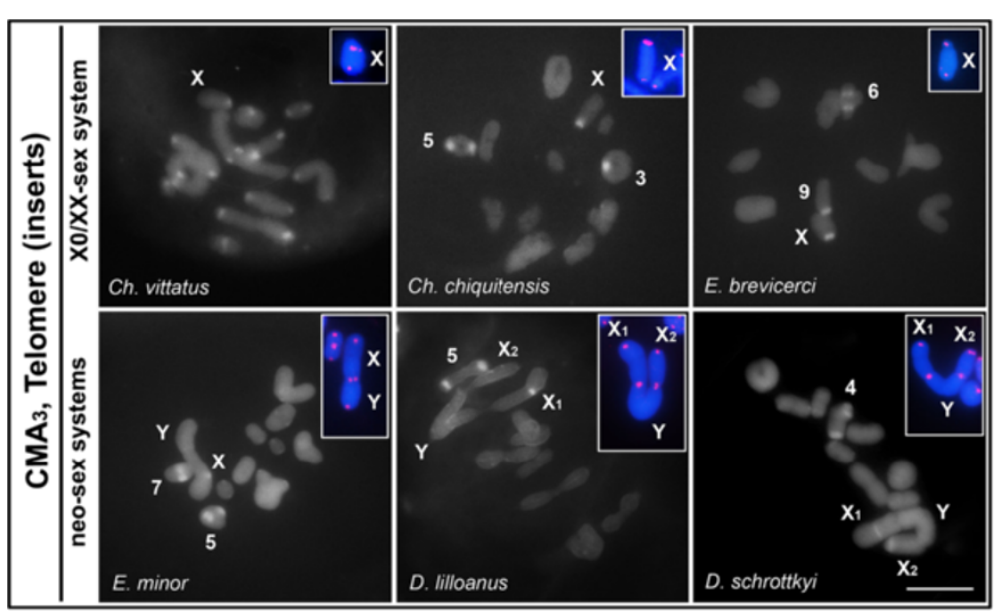

Figure $3 \mathrm{CMA}_{3}$ fluorochrome staining and FISH with a telomeric probe (insert) in male meiotic cells. The species names and sex chromosome system types are indicated in each figure. Additionally, autosomes with $\mathrm{CMA}_{3}$-positive blocks are indicated. Note the absence of interstitial telomeric sites in the neo-sex chromosomes produced by Rb-fusions. Bar $=5 \mu \mathrm{m}$. 


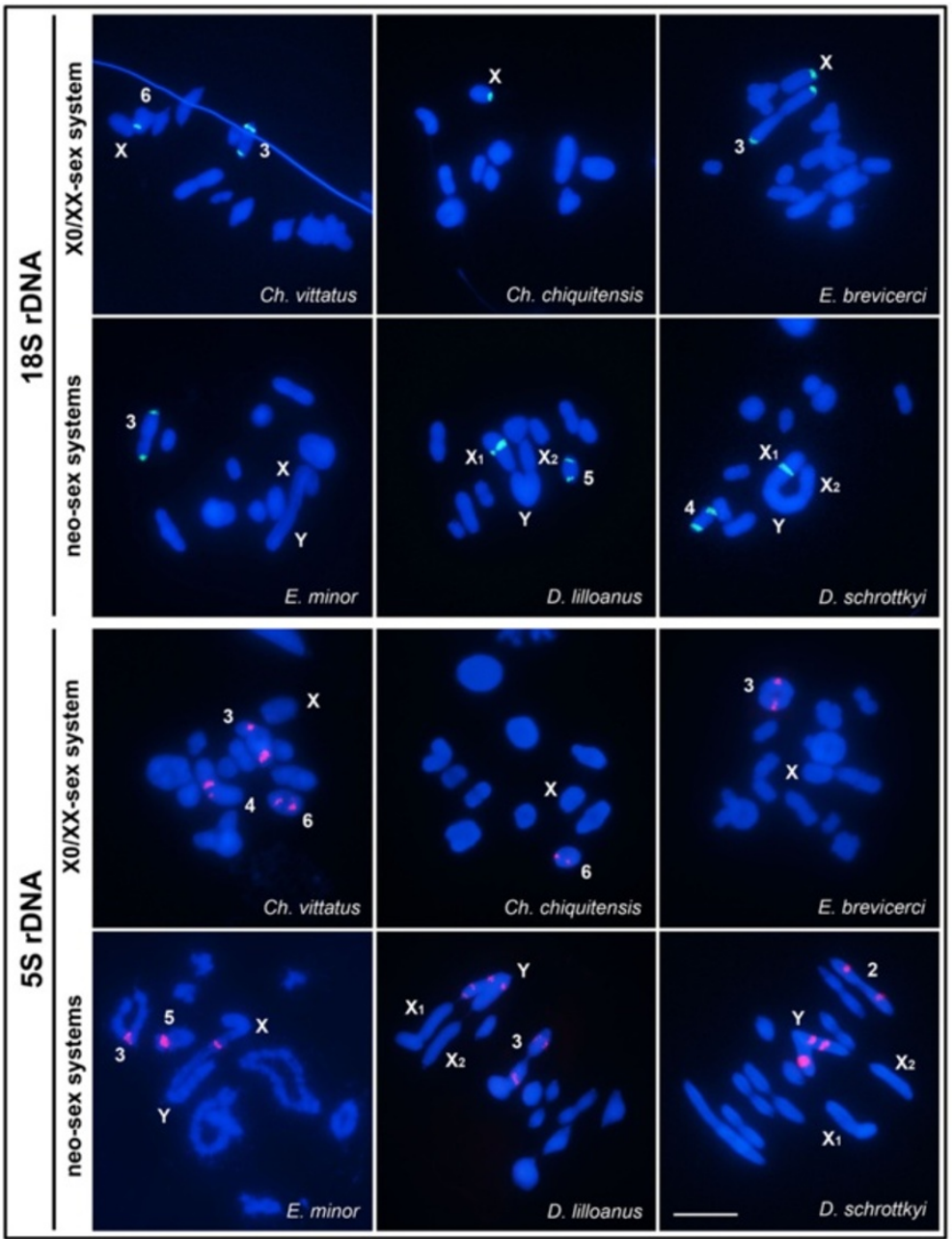

Figure 4 FISH with $18 \mathrm{~S}$ and $5 \mathrm{~S}$ rDNA probes in meiotic cells from males. The probe, type of sex-chromosome system and name of species are indicated in each figure. Chromosomes with positive signals and sex chromosomes are indicated. Note the presence of pericentromeric sites for $18 \mathrm{~S}$ rDNA on the X-chromosomes of Ch. chiquitensis and E. brevicerci and on the neo- $X_{1}$ chromosomes of D. lilloanus and D. schrottkyi, as well as the $5 \mathrm{~S}$ rDNA on the sex bivalent neo-XY chromosome of $E$. minor and in multiple sites on the neo-Y chromosome in $D$. lilloanus and $D$.

schrottkyi. Bar $=5 \mu \mathrm{m}$.

consistent with previous studies in which similar patterns were observed in grasshopper species [45-47] and in other insects, such as Lepidoptera [48], Coleoptera [49] and Heteroptera [50]. The variability for 5S rDNA also reflects common patterns seen in grasshoppers [47]. In contrast with the rDNAs, the Melanoplinae species analyzed here showed less variability in the U1 snRNA genes; this stability of the U1 snDNA clusters has been previously documented in other biological models, such as in cichlid fishes [51]. Although an additional U snRNA gene, U2 snRNA, showed more variability than U1 snRNA, it was also conserved in the interstitial position of pair 1 , potentially reflecting the ancestral placement in these species.

According to Cabrero et al. [52], the occurrence of one autosomal cluster of histone $\mathrm{H} 3$ genes represents the ancestral placement for Acrididae. This location was observed in our study for five of the species analyzed. However, it is possible that the unusual dispersion observed for the histone $\mathrm{H} 3$ genes in D. lilloanus, also observed for example in Abracris flavolineata [53], could be the result of multiple mechanisms, such as association with mobile elements, ectopic recombination or extrachromosomal circular DNA (eccDNA), as has been postulated for rDNAs [46,54-56].

\section{Diversification of the sex chromosomes}

As we mentioned above, the organization of different repetitive DNA sequences has been described in grasshoppers, mainly for multigene families $[46,47,52]$. However, there are no records of studies focusing on the possible role of such genomic elements in the diversification of sex chromosomes. 


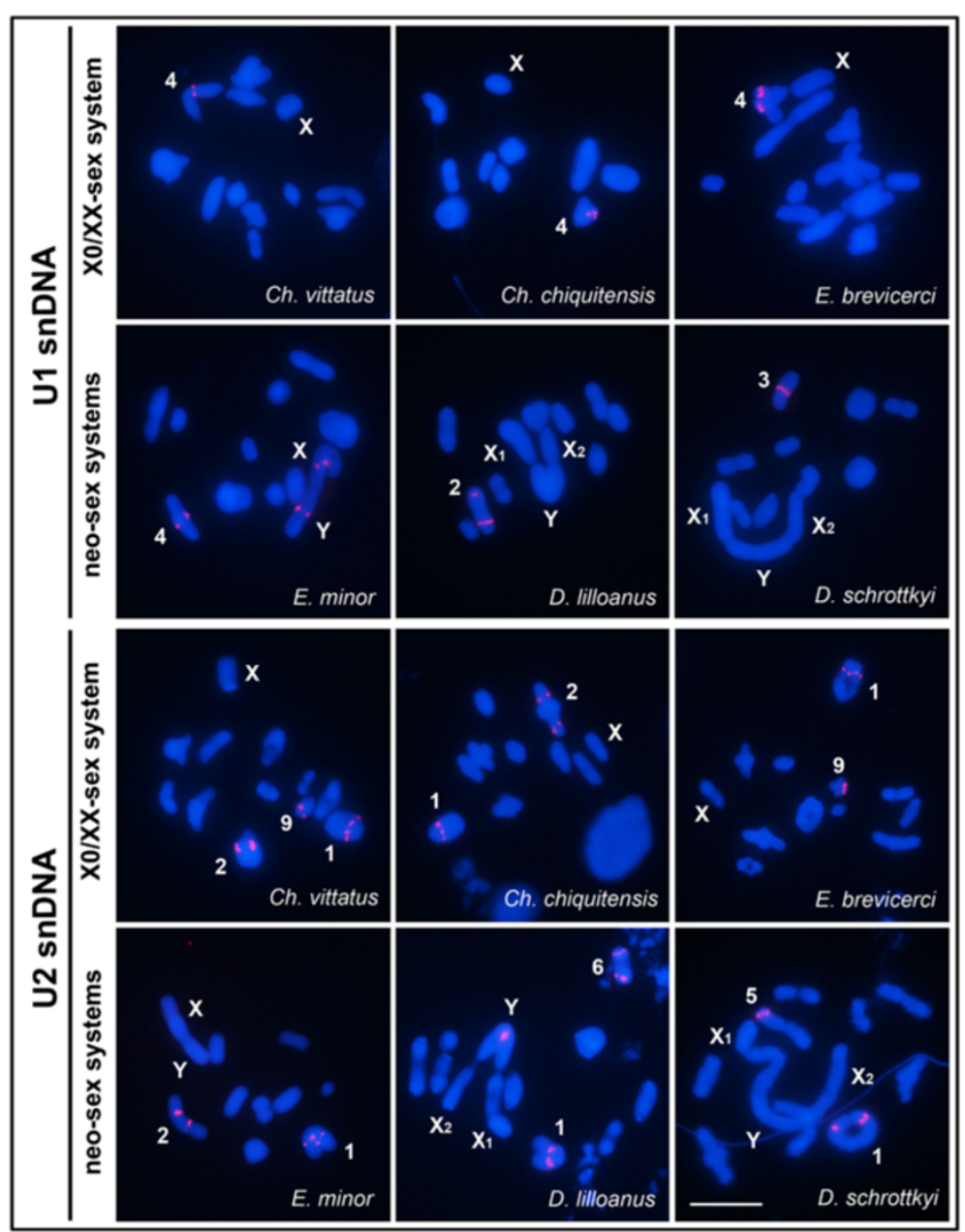

Figure 5 Chromosomal mapping of the U1 and U2 snRNA genes in meiotic cells from males. The probe type, sex chromosome system and name of species are shown for each cell. Chromosomes with positive hybridization signals and sex chromosomes are indicated in the images. Note the presence of U1 snDNA clusters in the interstitial region of the neo-XY chromosomes of E. minor, and the U2 snDNA clusters in the proximal region of the neo-Y chromosome of D. lilloanus. Bar $=5 \mu \mathrm{m}$.

C-positive blocks in the pericentromeric regions observed in the three different sex chromosome systems indicate non-spreading of heterochromatic segments after their origin. Additionally, the mapping of $C_{0} t-1$ DNA fractions reinforced the non-massive spreading of repetitive DNA pools in these sex chromosomes, which contrasts with the repetitive DNA accumulation expected on sex chromosomes after recombination restriction $[19,25,31$, 57]. An alternative hypothesis is that these chromosomes possess variable repetitive DNAs not isolated in the $C_{0} t-1$ DNA fraction.

For E. minor, D. schrottkyi and D. lilloanus, the mapping of the $C_{0} t-1$ DNA fraction suggested different evolutionary scenarios for the divergence of the neo-Y sex chromosomes. The results could be interpreted as evidence of the loss of selection pressure in the nonrecombining regions during their differentiation, leading to a high rate of genetic diversification in the neo-Y chromosome. In the D. lilloanus neo-Y chromosome, we observed the absence of a $C_{0} t-1$ DNA block compared with the E. minor and D. schrottkyi neo-Y chromosomes. Different accumulation/diversification patterns of repetitive DNAs in sex chromosomes were also documented for example in plants from the Rumex genus [23] and Parodontidae fish [58].

Considering the presence of all of the multigene families mapped in the sex chromosomes, we propose that these sequences could be involved in the diversification of the sex-chromosome determining mechanisms found in Melanoplinae. The $18 \mathrm{~S}$ rDNA mapping results indicate the independent evolution of the neo-XY and neo$\mathrm{X}_{1} \mathrm{X}_{2} \mathrm{Y}$ sex systems in the related genera Eurotettix and Dichromatos, due to the absence and presence of this marker in the $\mathrm{X}$ chromosomes, respectively. However, we could not rule out the possibility of transposition in these derived sex chromosomes. The noticeable 


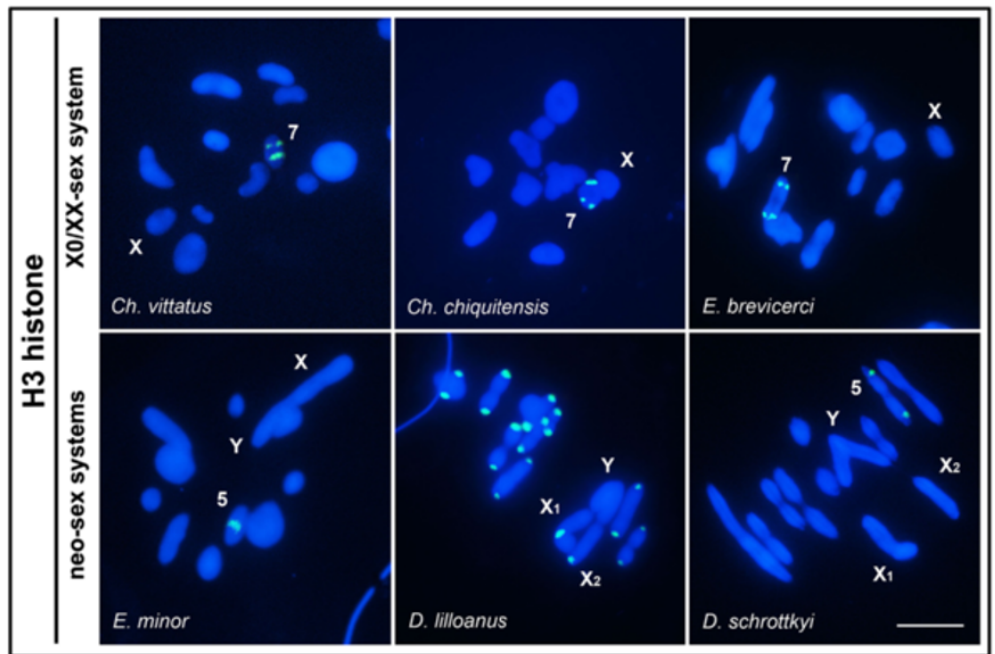

Figure 6 FISH for the histone $\mathrm{H} 3$ gene in male meiotic cells. Divergent sex chromosomes, names of species and the chromosomes with hybridization signals are indicated in the figure. Remarkably, the histone $\mathrm{H} 3$ gene cluster was found in pericentromeric regions of all chromosomes, except in the neo-Y in D. lilloanus. Bar $=5 \mu \mathrm{m}$.

accumulation of $5 \mathrm{~S}$ rDNA in the XR arm of E. minor and the neo-Y chromosome of D. lilloanus and $D$. schrottkyi could initially be attributed to Rb-fusion X-A and also due to the absence of recombination between sex chromosomes, with the gene cluster localized on the autosome involved in the rearrangement. Moreover, the presence of multiple sites containing $5 \mathrm{~S}$ rDNA on the neo-Y chromosome of D. lilloanus and D. schrottkyi suggests the strong accumulation of these sequences after chromosomal rearrangement or the potential action of intrachromosomal recombination, followed by amplification and transposition. The multiple sites observed for these sequences could make this region less likely to undergo recombination and allow it to play an important role in chromatin remodeling, as has been observed for other repetitive DNAs. The rDNA locus, located on sex chromosomes in salmonid fishes, for example, has been suggested to be involved in the restriction of crossing-over near the sex-determining locus [59].

The U1 snRNA gene did not show a strong relationship with sex chromosome diversification, occurring only in the neo-XY chromosome of E. minor; this result supports the existence of divergent evolutionary pathways from the Dichromatos neo-sex chromosomes. For D. lilloanus, the presence of U2 snDNA in the neo-Y chromosome demonstrates the diversification of this chromosome relative to the other congeneric species, $D$. schrottkyi. Although the histone $\mathrm{H} 3$ genes were present in the neo- $\mathrm{X}_{1}$ and neo- $\mathrm{X}_{2}$ chromosomes of $D$. lilloanus, this sequence was not apparently consistent with sex chromosome diversification; this phenomenon could be associated with the intrinsic mechanism of histone $\mathrm{H} 3$

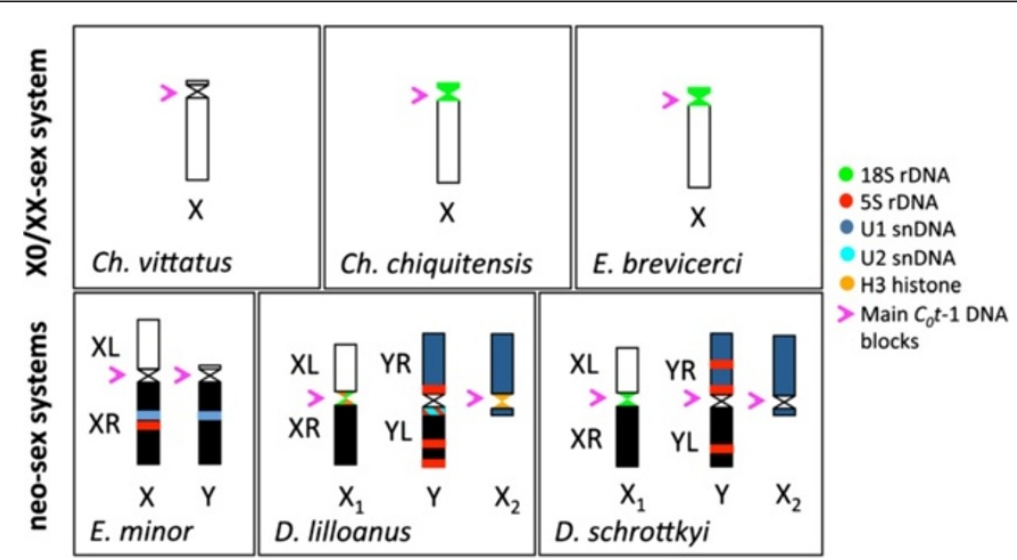

Figure 7 FISH signals with six probes in the sex chromosomes of all the species analyzed in this study. The probes and its position on the sex chromosomes are shown. Colors on the sex chromosomal arms represent the ancestral regions of homology. 
dispersion in the $D$. lilloanus genome after the divergence of the Dichromatos species.

Phylogenetic analyses suggest that Chlorus, Eurotettix and Dichromatos are monophyletic groups with uncertain evolutionary relationships to the rest of the $\mathrm{Di}$ chroplini tribe $[42,43]$. Considering the morphological characteristics of these species with all brachypterous species, and consequently low vagility, it is possible that the neo-sex chromosome systems might have played a significant role in the divergence and isolation between populations, leading to the restriction of gene flow and speciation. After isolation, the sex chromosomes could undergo molecular differentiation, as observed for the species studied here. Similar models of phenotypic divergence, reproductive isolation and speciation through neo-sex chromosomes have been proposed, for example, for closely related species of fishes [12].

Notably, neo-sex chromosome systems derived from autosome-sex chromosome fusion have been frequently reported in animals [3,12,60-62]. Such rearrangement results in specific intrinsic properties, such as recombinationfree regions, due to chiasmata shifts that lead to low intra-chromosomal recombination between involved chromosomes, and the reduction of linkage groups, resulting in lower rates of inter-chromosomal recombination $[3,15,21]$. According to Charlesworth et al. [20], these factors create strong linkage between the genes on evolving sex chromosomes, which is favorable in the heterogametic sex. These mechanisms might potentially be involved in sex chromosome diversification among Melanoplinae grasshoppers undergoing $\mathrm{Rb}$ fusions that result in reduced chromosome numbers. Indeed, we demonstrated in this study that the presence of telomeric sequences occurred only in current telomeres, which confirms a previous hypothesis that $\mathrm{Rb}$ fusions [32] originate from double chromosome breaks with the loss of telomeric sequences. Although we cannot rule out completely the occurrence of interstitial telomeric sites not detected by FISH.

\section{Conclusions}

Different organization of repetitive sequences in the sex chromosomes indicates independent diversification of the sex chromosome systems in Melanoplinae grasshoppers of the Chlorus, Eurotettix and Dichromatos genera. However, the localization of $18 \mathrm{~S}$ and $5 \mathrm{~S}$ rDNA on the neo- $\mathrm{X}_{1}$ and neo-Y chromosomes of Dichromatos species suggests that the neo- $\mathrm{X}_{1} \mathrm{X}_{2} \mathrm{Y}$ sex determination systems share a common origin, but these chromosomes have also undergone distinct modifications that led to their differentiation. In addition, the presence of structural genes (like 5S rRNA, U1 snRNA and U2 snRNA) mapped to the neo-Y chromosome of E. minor and Dichromatos species would prevent the complete degeneration and loss of these chromosomes
(X0 reversion). The results presented in this paper provide an initial characterization of the derived sex chromosomes in grasshoppers at a molecular level, focusing on the presence of repetitive DNA sequences. To obtain a more detailed picture of sex chromosome evolution in grasshoppers, future studies should be performed using crossspecies chromosome painting and the isolation of different repetitive DNAs, such as transposable elements and satellite DNAs.

\section{Methods}

\section{Animals, DNA samples and chromosome spreading}

Male and female adult grasshoppers from the species Chlorus vittatus, Ch. chiquitensis, Eurotettix brevicerci, E. minor, Dichromatos lilloanus and D. schrottkyi were sampled from distinct localities in Paraguay, Argentina and Brazil (Table 1). Male testes were fixed in a 3:1 ethanol: acetic acid solution, and female gastric caeca were removed and fixed as described by Castillo et al. [63]. All specimens were stored in $100 \%$ ethanol until subsequent DNA extraction.

We used conventional staining with 5\% Giemsa to visualize the general chromosomal characteristics present in the individuals of each species. C-banding was performed according to Sumner [64], and fluorochrome staining $\left(\mathrm{CMA}_{3} / \mathrm{DA} / \mathrm{DAPI}\right)$ was performed according to Schweizer et al. [65]. Genomic DNA extraction was performed using the phenol-chloroform protocol [66].

The nomenclature proposed by White [3] was used to describe the neo-sex chromosome arms in simple neo$\mathrm{XY}$ systems; the arms of neo-X chromosomes were designated $\mathrm{XL}$, which is the ancestral $\mathrm{X}$, and $\mathrm{XR}$, which shares homology with the neo-Y. In multiple neo- $\mathrm{X}_{1} \mathrm{X}_{2} \mathrm{Y}$ systems, the neo- $\mathrm{X}_{1}$ chromosome was designated as described for the neo-XY type; the metacentric neo- $\mathrm{Y}$ chromosome is formed from the YL and YR arms, which share homology with the $\mathrm{XR}$ and neo- $\mathrm{X}_{2}$ chromosome, respectively.

\section{Isolation of multigene families and telomeric repeats}

The partial sequences of the 5S rRNA and histone $\mathrm{H} 3$ genes were amplified by polymerase chain reaction (PCR) using genomic DNA obtained from Abracris flavolineata and the primers described by Loreto et al. [67] and Cabral-de-Mello et al. [68] for 5S rDNA and Colgan et al. [69] for histone H3. The sequences for the $\mathrm{U}$ snDNAs were obtained from the Rhammatocerus brasiliensis genome using primers described by Cabralde-Mello et al. [51] for U1 snDNA and Bueno et al. [53] for U2 snDNA. The amplified fragments were sequenced and deposited in GenBank under the accession numbers KC936996 (5S rDNA), KC896792 (histone H3 gene), KC896793 (U1 snDNA) and KC896794 (U2 snDNA). 
The $18 \mathrm{~S}$ rDNA sequence was obtained from a cloned fragment previously isolated from the Dichotomius se misquamosus genome (GenBank accession number GQ443313, Cabral-de Mello et al. [68]), and the telomeric probes were obtained by PCR using the complementary primers (TTAGG) 5 and (CCTAA) ${ }_{5}$ [70].

\section{$\mathrm{C}_{0} \mathrm{t}-1$ DNA isolation}

Repetitive DNA-enriched samples from each species were obtained based on the renaturation kinetics of $C_{0} t$ 1 DNA (DNA enriched for highly and moderately repetitive DNA sequences), according to the protocol described by Zwick et al. [71] with modifications [68]. Briefly, the DNA samples $(200 \mu \mathrm{L}$ of $100-500-\mathrm{ng} / \mu \mathrm{L}$ genomic DNA in $0.3 \mathrm{M} \mathrm{NaCl}$ ) were digested with deoxyribonuclease I (Sigma, St Louis, MO, USA) at $0.01 \mathrm{U} / \mu \mathrm{L}$ for 80 to $105 \mathrm{sec}$, depending on the sample concentration, and the fragmented DNA was separated using $1 \%$ agarose gel electrophoresis. The expected DNA fragments ranged in size from 100 to 1,000 base pairs (bp). For each species, $50 \mu \mathrm{L}$ samples of the fragmented DNA were denatured at $95^{\circ} \mathrm{C}$ for $10 \mathrm{~min}$, placed on ice for 10 sec and transferred to a $65^{\circ} \mathrm{C}$ water bath to reanneal for $25 \mathrm{~min}$. Subsequently, the samples were incubated at $37^{\circ} \mathrm{C}$ for 8 min with $1 \mathrm{U}$ of S1 nuclease to digest the single-stranded DNA. The DNA was purified and extracted using a traditional phenol-chloroform protocol [66].

\section{Fluorescence in situ hybridization}

The plasmid containing the 18S rRNA gene, the PCR products from the histone $\mathrm{H} 3$ gene and the $C_{0} t-1$ DNA fraction were labeled by nick translation using biotin14-dATP (Invitrogen, San Diego, CA, USA). The 5S rDNA, U snDNAs (U1, U2) and telomeric probes were PCR labeled with digoxigenin-11-dUTP (Roche, Mannheim, Germany).

Single- or two-color FISH was performed according to Pinkel et al. [72], with modifications [68] using distinct mitotic and meiotic cells. Although some twocolor FISH assays were performed, the same metaphase is shown separately for each probe. Probes labeled with digoxigenin-11-dUTP were detected using anti-digoxigenin-rhodamine (Roche), and probes labeled with biotin-14-dATP were detected using streptavidin, alexa fluor 488 conjugate (Invitrogen). The preparations were counterstained using $4^{\prime}$, 6-diamidine- $2^{\prime}$ phenylindole dihydrochloride (DAPI) and mounted using Vectashield (Vector, Burlingame, CA, USA). The chromosomes and FISH signals were observed using an Olympus microscope BX61 equipped with a fluorescence lamp and appropriate filters. The photographs were recorded using a DP70 cooled digital camera. The images were merged and optimized for brightness and contrast using Adobe Photoshop CS2 software.

\section{Abbreviations}

2n: diploid number; Bp: Base pairs; $\mathrm{CMA}_{3}$ : Chromomycin $\mathrm{A}_{3} ; \mathrm{C}_{0}$ : $\mathrm{C}_{0}$ is the initial concentration of single-stranded DNA in $\mathrm{mol} / \mathrm{l}$ and $t$ is the reannealing time in seconds; DA: Distamicyn; DAPI: 4', 6-Diamidino-2-phenylindole; FISH: Fluorescence in situ hybridization; PCR: Polymerase chain reaction; Rbfusion: Robertsonian fusion; rDNA: Ribosomal DNA; rRNA: Ribosomal RNA; snRNA: Small nuclear RNA.

\section{Competing interests}

The authors declare that they have no competing interests.

\section{Authors' contributions}

OMPG conducted the chromosome preparations and the molecular cytogenetic experiments, interpreted the data, and drafted of the manuscript. ERC and DAM interpreted the data and drafted the manuscript. DCCM conceived the study, participated in its design and coordination, interpreted the data and assisted in drafting the manuscript. All authors have read and approved the final manuscript.

\section{Acknowledgements}

The authors are grateful to Dr. María Marta Cigliano for the taxonomic identification of the species studied and Dr. Amilton Ferreira for collecting some samples, and to the anonymous reviews for the comments. This study was supported by funding from the Fundação de Amparo a Pesquisa do Estado de São Paulo-FAPESP (2011/19481-3, 2012/01421-7), Coordenadoria de Aperfeiçoamento de Pessoal de Nível Superior-CAPES, Conselho Nacional de Desenvolvimento Científico e Tecnológico-CNPq (475308/2011-5), PROPE/ UNESP and Consejo Nacional de Investigaciones Científicas y TécnicasCONICET.

\section{Author details}

${ }^{1}$ UNESP - Univ Estadual Paulista, Instituto de Biociências/IB, Depto. de Biologia, Rio Claro/SP, Brazil. ' Laboratorio de Genética Evolutiva, IBS, Facultad de Ciencias Exactas, Químicas y Naturales, Universidad Nacional de Misiones, Posadas 3300, Argentina.

Received: 14 May 2013 Accepted: 5 August 2013

Published: 9 August 2013

\section{References}

1. McClung CE: The spermatocyte divisions of the Acrididae. Kansas University Quarterly 1900, 9:73-100.

2. Stevens NM: Studies in spermatogenesis: a comparative study of the heterochromosomes in certain species of Coleoptera, Hemiptera, and Lepidoptera, with especial reference to sex determination. Carnegie Institution of Washington 1906, 36:33-75.

3. White MJD: Animal Cytology and Evolution. Cambridge: Cambridge University Press; 1973.

4. Hewitt GM: Grasshoppers and crickets. Animal Cytogenetics. vol 3: Insecta 1. Orthoptera. Berlin: Gebrüder Borntraeger; 1979.

5. Yi S, Charlesworth B: Contrasting patterns of molecular evolution of the genes on the new and old sex chromosomes of Drosophila miranda. Mol Biol Evol 2000, 17:703-717.

6. Bachtrog D: A dynamic view of sex chromosome evolution. Curr Opin Genetic Dev 2006, 16:578-85.

7. Vibranovsky MD, Koerich $L B$, Carvalho AB: Two new Y-linked genes in Drosophila melanogaster. Genetics 2008, 179:2325-2327.

8. Graves JAM: Weird animal genomes and the evolution of vertebrate sex and sex chromosomes. Annu Rev Genet 2008, 42:565-86.

9. Sánchez L: Sex-determining mechanisms in insects. Int J Dev Biol 2008, 52:837-856.

10. Verhulst EC, van de Zande L, Beukeboom LW: Insect sex determination: it all evolves around transformer. Curr Opin Genet Dev 2010, 20:376-383.

11. Griffin DK: Is the $Y$ chromosome disappearing? Both sides of the argument. Chromosome Res 2012, 20:35-45.

12. Kitano J, Peichel CL: Turnover of sex chromosomes and speciation in fishes. Environ Biol Fish 2012, 94:549-558.

13. Ohno S: Sex Chromosomes and Sex Linked Genes. Berlin: Springer; 1967.

14. Bull Jj: Evolution of Sex Determining Mechanisms. Menlo Park, CA: Benjamin Cummings; 1983. 
15. Bachtrog D, Charlesworth B: Reduced adaptation of a nonrecombining neo-Y chromosome. Nature 2002, 416:323-26.

16. Kaiser VB, Bachtrog D: Evolution of sex chromosomes in insects. Annu Rev Genet 2010, 44:91-112.

17. Charlesworth B, Sniegowski P, Stephan W: The evolutionary dynamics of repetitive DNA in eukaryotes. Nature 1994, 371:215-220.

18. Rice WR: Evolution of the $Y$ sex chromosome in animals. Bioscience 1996 , 46:331-343.

19. Steinemann $M$, Steinemann $S$ : The enigma of $Y$ chromosome degeneration: TRAM, a novel retrotransposon is preferentially located on the neo-Y chromosome of Drosophila miranda. Genetics 1997, 145:261-266.

20. Charlesworth D, Charlesworth B, Marais G: Steps in the evolution of heteromorphic sex chromosomes. Heredity 2005, 95:118-128.

21. Steinemann S, Steinemann M: Retroelements: tools for sex chromosome evolution. Cytogenet Genome Res 2005, 110:134-143.

22. Hobza R, Kejnovsky E, Vyskot B, Widmer A: The role of chromosomal rearrangements in the evolution of Silene latifolia sex chromosomes. Mol Genet Genomics 2007, 278:633-638.

23. Navajas-Pérez R, del Bosque ME Q, Garrido-Ramos MA: Effect of location, organization, and repeat-copy number in satellite-DNA evolution. Mol Genet Genomics 2009, 282:395-406.

24. Kejnovsky E, Hobza R, Cermak T, Kubat Z, Vyskot B: The role of repetitive DNA in structure and evolution of sex chromosomes in plants. Heredity 2009, 102:533-541.

25. Matsunaga S: Junk DNA promotes sex chromosome evolution. Heredity 2009, 102:525-526.

26. Skaletsky H, Kuroda-Kawaguchi T, Minx PJ, Cordum HS, Hillier L, Brown LG, Reppping S, Pyntikova T, Ali J, Bieri T, et al: The male-specific region of the human $Y$ chromosome is a mosaic of discrete sequence classes. Nature 2003, 423:825-837.

27. Steinemann M, Steinemann S: Common mechanisms of $Y$ chromosome evolution. Genetica 2000, 109:105-111.

28. Graves JAM: Recycling the $Y$ chromosome. Science 2005, 307:50-51.

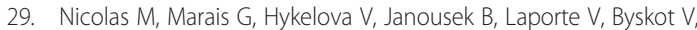
Mouchiroud D, Negrutiu I, Charlesworth D, Monéger F: A gradual process of recombination restriction in the evolutionary history of the sex chromosomes in dioecious plants. PLOS Biol 2004, 3:e4.

30. Hobza R, Lengerova M, Svoboda J, Kubekova H, Kejnovsky E, Vyskot B: An accumulation of tandem DNA repeats on the $\mathrm{Y}$ chromosome in Silene latifolia during early stages of sex chromosome evolution. Chromosoma 2006, 115:376-382.

31. Bergero R, Charlesworth D: The evolution of restricted recombination in sex chromosomes. Trends in Ecology and Evolution 2008, 24:94-102.

32. White MJD: Modes of Speciation. San Francisco: WH Freeman and Company; 1978

33. Mesa A, Ferreira A, Carbonell CS: Cariología de los acridoideos neotropicales: estado actual de su conocimiento y nuevas contribuciones. Annales de la Societé Entomologique de France 1982, 18:507-526.

34. Castillo ERD, Bidau CJ, Martí DA: Neo-sex chromosome diversity in neotropical melanopline grasshoppers (Melanoplinae, Acrididae). Genetica 2010, 138:775-786.

35. Castillo ER, Martí DA, Bidau CJ: Sex and neo-sex chromosomes in Orthoptera: a review. Juornal of Orthoptera Research 2010, 19:213-231.

36. Mesa A, Fontanetti CS, García Novo P: Does an X-autosome centric fusión in Acrdoidea condemn the species to extinction? Journal of Orthoptera Research 2001, 10:141-146.

37. Bidau CJ, Martí DA: Meiosis and the Neo-XY of Dichroplus vittatus (Melanoplinae, Acrididae): a comparison between sexes. Genetica 2001, 110:185-194.

38. Traut W, Sahara K, Marec F: Sex chromosomes and sex determination in Lepidoptera. Sex Dev 2007, 1:332-346.

39. Vítková M, Fuková I, Kubíčková S, Marec F: Molecular divergence of the W chromosomes in pyralid moth (Lepidoptera). Chromosome Res 2007, 15:917-930

40. Sahara K, Yoshido A, Traut W: Sex chromosome evolution in moth and butterflies. Chromosome Res 2012, 20:83-94.

41. Nguyen P, Sýkorová M, Šíchová J, Kůta V, Dalíková M, Frydrychová RC, Neven LG, Sahara K, Marec F: Neo-sex chromosomes and adaptive potential in tortricid pests. Proc Natl Acad Sci U S A 2013, 110:6931-6936.

42. Cigliano MM: Review of the South American genus Eurotettix Bruner (Orthoptera, Acridoidea, Melanoplinae). Systematic Entomology 2006, 32:176-195.
43. Cigliano MM, Lange CE: Systematic revision and phylogenetic analysis of the South American genus Chlorus (Orthoptera, Acridoidea, Melanoplinae). Zoologica Scripta 2007, 36:241-254.

44. Santos JL, Arana P, Giráldez L: Chromosome C-banding patterns in Spanish Acridoidea. Genetica 1983, 61:65-74.

45. John B, King M: The inter-relationship between heterochromatin distribution and chiasma distribution. Genetica 1985, 66:183-194.

46. Cabrero J, Camacho JP: Location and expression of ribosomal RNA genes in grasshoppers: Abundance of silent and cryptic loci. Chromosome Res 2008, 16:595-607.

47. Cabral-de-Mello DC, Cabrero J, López-León MD, Camacho JPM: Evolutionary dynamics of 5S rDNA location in acridid grasshoppers and its relationship with $\mathrm{H} 3$ histone gene and $45 \mathrm{~S}$ rDNA location. Genetica 2011, 139:921-931.

48. Nguyen P, Sahara K, Yoshido A, Marec F: Evolutionary dynamics of rDNA clusters on chromosomes of moths and butterflies (Lepidoptera). Genetica 2010, 138:343-354.

49. Cabral-de-Mello DC, Oliveira SG, Moura RC, Martins C: Chromosomal organization of the $18 \mathrm{~S}$ and $5 \mathrm{~S}$ rRNAs and histone $\mathrm{H} 3$ genes in Scarabaeinae coleopterans: insights into the evolutionary dynamics of multigene families and heterochromatin. BMC Genet 2011, 12:88.

50. Panzera Y, Pita S, Ferreiro MJ, Ferrandis I, Lages C, Pérez R, Silva AE, Guerra $\mathrm{M}$, Panzera F: High dynamics of rDNA cluster location in kissing bug holocentric chromosomes (Triatominae, Heteroptera). Cytogenet Genome Res 2012, 138:56-67.

51. Cabral-de-Mello DC, Valente GT, Nakajima RT, Martins C: Genomic organization and comparative chromosome mapping of the U1 snRNA gene in cichlid fish, with an emphasis in Oreochromis niloticus. Chromosome Res 2012, 20:279-292.

52. Cabrero J, López-León MD, Teruel M, Camacho JP: Chromosome mapping of $\mathrm{H} 3$ and $\mathrm{H} 4$ histone gene clusters in 35 species of acridid grasshoppers. Chromosome Res 2009, 17:397-404.

53. Bueno D, Palacios-Gimenez OM, Cabral-de-Mello DC: Chromosomal mapping of repetitive DNAs in Abracris flavolineata reveal possible ancestry for the $\mathrm{B}$ chromosome and surprisingly $\mathrm{H} 3$ histone spreading. PLOS ONE 2013, 8:e66532.

54. Cohen S, Yacobi K, Segal D: Extrachromosomal circular DNA of tandemly repeated genomic sequences in Drosophila. Genome Res 2003, 13:1133-1145.

55. Cohen S, Agmon N, Sobol O, Segal D: Extrachromosomal circles of satellite repeats and 5S ribosomal DNA in human cells. Mob DNA 2010, 1:11.

56. Nei M, Rooney AP: Concerted and birth-and-death evolution of multigene families. Annu Rev Genet 2005, 39:121-52.

57. Kejnovsky E, Michalovova M, Steflova P, Kejnovska I, Manzano S, Hobza R, Kubat Z, Kovarik J, Jamilena M, Vyskot B: Expansion of microsatellites on evolutionary young Y chromosome. PLOS ONE 2013, 8:e45519.

58. Schemberger MO, Bellafronte $E$, Nogaroto V, Almeida MC, Schühli GS, Artoni RF, Moreira-Filho O, Vicari MR: Differentiation of repetitive DNA sites and sex chromosome systems reveal closely related group in Parodontidae (Actinopterygii: Characiformes). Genetica 2011, 139:1499-1508.

59. Reed KM, Phillips RB: Polymorphism of the nucleolus organizer region (NOR) on the putative sex chromosomes of Arctic char (Salvelinus alpinus) is not sex related. Chromosome Res 1997, 5:221-227.

60. Grützner F, Rens W, Tsend-Ayushl E, El-Mogharbel N, O'Brien PCM, Jones RC, Ferguson-Smith MA, Marshall Graves JA: In the platypus a meiotic chain of ten sex chromosomes shares genes with the bird $Z$ and mammal $X$ chromosomes. Nature 2004, 432:913-917.

61. Yoshida K, Kitano J: The contribution of female meiotic drive to the evolution of the neo-sex chromosomes. Evolution 2012, 66:3198-3208.

62. Yoshido A, Šíchová J, Kubíčková S, Marec F, Sahara K: Rapid turnover of the W chromosome in geographical populations of wild silkmoths, Samia cynthia ssp. Chromosome Res 2013, 21:149-164.

63. Castillo ER, Taffarel A, Martí DA: Una técnica alternativa para el cariotipado mitótico en saltamontes: bandeo $C$ y Fluorescente en Adimantus ornatissimus (Orthoptera: Acrididae). Rev Cienc Tecnol 2011, 16:31-35.

64. Sumner AT: A simple technique for demonstrating centromeric heterochromatin. Exp Cell Res 1972, 75:304-306.

65. Schweizer D, Mendelak M, White MJD, Contreras N: Cytogenetics of the parthenogenetic grasshopper Warramaba virgo and its bisexual relatives. X. Pattern of fluorescent banding. Chromosoma 1983, 88:227-236.

66. Sambrook J, Russel DW: Molecular cloning. A laboratory manual. 3rd edition. New York: Cold Spring Harbor Laboratory Press; 2001. 
67. Loreto V, Cabrero J, López-León MD, Camacho JPM, Souza MJ: Possible autosomal origin of macro B chromosomes in two grasshopper species. Chromosome Res 2008, 16:233-241.

68. Cabral-de-Mello DC, Moura RC, Martins C: Chromosomal mapping of repetitive DNAs in the beetle Dichotomius geminatus provides the first evidence for an association of $5 \mathrm{~S}$ rRNA and histone $\mathrm{H} 3$ genes in insects, and repetitive DNA similarity between the $B$ chromosome and $A$ complement. Heredity 2010, 104:393-400.

69. Colgan DJ, McLauchlan A, Wilson GDF, Livingston SP, Edgecombe GD, Macaranas J, Cassis G, Gray MR: Histone H3 and U2 snRNA DNA sequences and arthropod molecular evolution. Austral I Zool 1998 46:419-437.

70. Ijdo JW, Wells RA, Baldini A, Reeders ST: Improved telomere detection using a telomere repeat probe (TTAGGG)n generated by PCR. Nucleic Acids Res 1991, 19:4780.

71. Zwick MS, Hanson RE, McKnight TD, Nurul-slam-Faridi M, Stelly DM: A rapid procedure for the isolation of $C_{0} t-1$ DNA from plants. Genome 1997, 40:138-142.

72. Pinkel D, Straume T, Gray JW: Cytogenetic analysis using quantitative, high-sensitivity, fluorescence hybridization. Proc Natl Acad Sci USA 1986, 83:2934-2938

doi:10.1186/1471-2148-13-167

Cite this article as: Palacios-Gimenez et al:: Tracking the evolution of sex chromosome systems in Melanoplinae grasshoppers through chromosomal mapping of repetitive DNA sequences. BMC Evolutionary Biology 2013 13:167.

\section{Submit your next manuscript to BioMed Central and take full advantage of:}

- Convenient online submission

- Thorough peer review

- No space constraints or color figure charges

- Immediate publication on acceptance

- Inclusion in PubMed, CAS, Scopus and Google Scholar

- Research which is freely available for redistribution 